\title{
Pharmaciana
}

Vol.9, No.2, Nov 2019, Page. 271-282

ISSN: 2088 4559; e-ISSN: 24770256

DOI: $10.12928 /$ pharmaciana.v9i2.12652

\section{Standardization of durian fruit peels (Durio zibethinus Murr.) extract and antioxidant activity using DPPH method}

\author{
Muhtadi*, Utami Ningrum \\ Departement of Pharmaceutical Chemistry, Faculty of Pharmacy, \\ Universitas Muhammadiyah Surakarta
}

\begin{abstract}
Durian fruit peels (Durio zibethinus Murr.) has been studied previously and reported to have pharmacological activity that has the potential to be antioxidant and antihypercholesterol. The ethanolic extracts of Durian fruit peels contained secondary metabolites, namely flavonoids, polyphenols, carotenes, and saponins. The purpose of this study to determine the non-specific parameters and specific parameters of the ethanol extract of durian fruit peels and to evaluate the antioxidant activity with the DPPH method. Standardization of herbal ingredients is an important thing to do so that the safety and quality of herbal medicines can be maintained. Two different cultivars of durian fruit peels are used, there are Medan and Monthong. The results of non-specific parameters between Medan and Monthong cultivars showed different moisture content $(9.71 \pm 0.96 ; 12.06 \pm$ $0.34 \%$, respectively), ash values $(1.03 \pm 0.20 ; 1.78 \pm 0.07 \%$, respectively), and water content $(6.12 \pm$ $0.29 ; 7.16 \pm 0.25 \%$ respectively). Medan and Monthong cultivar extracts showed specific parameters showed different organoleptic information such as odor, color, and physical appearance, the content of water soluble compounds $(36.39 \pm 1.90 \%)$, the value of ethanol soluble compounds $(40.20 \pm 0.19$; $45.27 \pm 1.02 \%$, respectively), and flavonoid value $(472 \pm 49.00 ; 310 \pm 13.45 \mathrm{mg} / \mathrm{g}$ sample), phenolic value $\left(245 \pm 5.15 ; 148 \pm 8.54 \mathrm{mg} / \mathrm{g}\right.$ sample). Antioxidant activity was indicated by $\mathrm{IC}_{50}$ values of each extract, namely Medan of $78.83 \pm 1.67 \mu \mathrm{g} / \mathrm{mL}$ and Monthong of $72.77 \pm 6.60 \mu \mathrm{g} / \mathrm{mL}$. Statistical tests showed the value of non-specific parameters and specific parameters of the two cultivars not differed significantly.
\end{abstract}

Keywords: Durian fruit peels, non specific parameters, specific parameters, standardization, antioxidant activity

\footnotetext{
*Corresponding author:

Muhtadi

Departement of Pharmaceutical chemistry, Faculty of Pharmacy

Universitas Muhammadiyah Surakarta

E-mail: muhtadi@ums.ac.id
} 


\section{INTRODUCTION}

Durian (Durio zibethinus Murr.) is an exotic fruit with a high bioactive content that has the potential to have pharmacological effects (Gorinstein et al., 2011). Fruit peels are one part of durian which can be developed as a raw material for herbal medicine because it has antioxidant, antidiabetic, and antihypercholesterol pharmacological effects (Batubara et al., 2009; Batubara; 2011; Muhtadi et al., 2014; Leontowicz et al., 2011). Muhtadi et al., (2016) reported that durian fruit peels were proven to reduce cholesterol levels in blood serum of rats equivalent to that of Cholesterolamine as a positive control. Leontowicz et al. (2008) stated that durian can significantly inhibit the increase of plasma lipids. Subsequent research Leontowicz et al.(2011) reported that inhibition of increased lipid was due to the role of antioxidant activity produced by the active polyphenol and flavonoid compounds.

Flavonoid compounds contained in durian fruit peels are routine and quercetin (Dembitsky et al, 2011). Durian fruit peels also contains $\beta$-carotene, saponin (Rahayu, 2007), tannin and polyphenols. Phenolic compounds that have been isolated from the peels of durian fruit are 3-E-ferulyloxy-lup20(29)-en-28-oic acid. This compound had the potential antioxidant activity (Muhtadi et al., 2014).

Leontowicz et al. (2011) examined Monthong cultivar originating from eastern Thailand, showing antioxidant activity of $1.12 \mu \mathrm{MTE} / \mathrm{g}$. Batubara (2011) used durian fruit peels originating from Indonesia in their research and reported the results of antioxidant activity of $61.57 \mu \mathrm{g} / \mathrm{mL}$. Experiments conducted showed different trends in results. This proves that the chemical content of medicinal plants is not always the same because of the influencing factors such as differences in geographical location, process of planting, post-harvest and final preparation so that the quality and content of chemicals from plants becomes varied (Kunle et al., 2012).

The difference in chemical content can affect the pharmacological effects produced. The varied chemical content also has various side effects (Pandey and Tripathi, 2014). Limited standard standards add to the difficulty of searching for the problem. Medicinal plants require tools to determine identity, purity and quality so that their properties are maintained (Sachan et al., 2016). Standardization is an effort that can be done to control the quality of raw materials for medicinal plants. Standardization is the process of formulating a set of characteristic standards to obtain guarantees of quality, efficacy, and security (EMEA, 2005). Standardization is a quality assurance process so that medicinal plants have constant parameter values (Arifin et al., 2006).

The objective of the study was to determine specific and non-specific parameters for herbal medicinal ingredients as suggested by the Indonesian Ministry of Health and the Food and Drug Inspection Agency. Non-specific parameters was measured, including shrinkage, air content, and ash content. While the specific parameters include organoleptics, chromatogram profiles, total phenolic, and flavonoid content. Testing of antioxidant activity using the DPPH method.

\section{MATERIALS AND METHOD Materials}

The material used is durian fruit peels obtained from the Bogor area. Durian used is Medan cultivar with the age of picking $100 \pm 3$ days (ripe) and Monthong with the age of picking $85 \pm 3$ days (mature). The part of the durian fruit peel that is used is the inside (white) and the outside (green).

\section{Extraction}

The peels of dried durian fruit with drying by the drier cabinet were pollinated, then macerated using $96 \%$ ethanol for 2 days. The liquid extracts were filtered using a vacuum device. The filters were evaporated with a rotary evaporator, after which it were concentrated on a water bath until a thick extract were obtained called durian fruit peels extracts. Remaseration process was done twice.

\section{Shrinkage drying measurement}

One gram of extract was put into a closed weighing bottle which had undergone heating conditioning and then weighed empty. The extract is put into the oven at $105^{\circ} \mathrm{C}$ with the lid open. The 
weighing bottle is inserted into the exicator so that the temperature drops to room temperature. This work is carried out repeatedly until a fixed weight is obtained (the difference between the weighing weight and the weighing before no more than 0,0005 g) (Departemen Kesehatan, 2000).

\section{Moisture measurement}

The extract $(3 \mathrm{~g})$ in aluminum foil, put in a dry round bottom flask. Fifty $\mathrm{mL}$ of toluene is added to the flask through a cooler (vertical condenser). the pumpkin is heated carefully for 1 hour. The inside of the cooler is rinsed with toluene. Water and toluene droplets are awaited until they are completely separated, the water volume is read (Departemen Kesehatan, 2000).

\section{Determination of ash content}

One gram of extract is put into the silicate crucible which has been previously spawned and weighed empty. The extract is gently spawned until the charcoal is exhausted, cooled in the eczema, then weighed. Work is done repeatedly until a fixed weight is obtained (Departemen Kesehatan, 2000).

\section{Determination of acid insoluble ash content}

Ash obtained from the determination of ash content, boiled with $25 \mathrm{~mL} 10 \%$ sulfuric acid for 5 minutes. The ash is filtered with non-ash filter paper, washed with hot water, spilled until the weight is fixed (Departemen Kesehatan, 2000).

\section{Determination of compounds dissolved in certain solvents}

Medan and Monthong cultivar extracts each weighed $1.5 \mathrm{~g}$. Weighing was done twice, labeled extract A and extract B. Extract A was macerated in a clogged flask for 1 day with $50 \mathrm{~mL}$ of waterchloroform and B extract was macerated for 1 day with $50 \mathrm{~mL}$ ethanol $96 \%$, the results of maceration were filtered, then $10.0 \mathrm{~mL}$ the filtrate is evaporated in a cup with an empty weight. The residue is heated at a temperature of $105^{\circ} \mathrm{C}$ to a fixed weight (Departemen Kesehatan, 2000).

\section{Chromatogram profile}

The extract solution was made by dissolving $50 \mathrm{mg}$ of extract into effendorp with ethanol solvent. The extract solution is bottled on the GF-254 silica plate. Elution is carried out by the mobile phase of chlorophome: methanol (8: 2). Identification was carried out under $366 \mathrm{~nm}$ UV light and visible light. Spray reagent is used for spot visualization resulting from the elution process. Reagents used were sitroborat, $\mathrm{FeCl}_{3}$, and DPPH (Departemen Kesehatan, 2000).

\section{Antioxidant assay}

The radical capture test using the DPPH (2,2-diphenyl-1-picryl-hydrazyl) method refers to the research of Rahayu (2007) with modifications. DPPH powder $15.8 \mathrm{mg}$ was dissolved in $100.0 \mathrm{~mL}$ absolute ethanol $(0.4 \mathrm{mM})$. The blanks used were absolute ethanol and vitamin $\mathrm{E}$ as positive controls. The maximum wavelength $(\lambda \max )$ DPPH is $515.9 \mathrm{~nm}$ and the incubation time is 45 minutes, measured on the Vis-spectrophotometer. Vitamin E, ethanol extract weighed $10 \mathrm{mg}$ in $10.0 \mathrm{~mL}$ absolute ethanol $(0.1 \%)$ as a stock solution. The vitamin E concentration series was made from stock solutions with a volume of $30 \mu \mathrm{L}, 40 \mu \mathrm{L}, 50 \mu \mathrm{L}, 60 \mu \mathrm{L}, 70 \mu \mathrm{L}$. The test solution concentration series was made from extract stock solution with a volume of $100 \mu \mathrm{L}, 200 \mu \mathrm{L}, 300 \mu \mathrm{L}, 400 \mu \mathrm{L}, 500 \mu \mathrm{L}$. The vitamin E solution and the test solution were put into a $5.0 \mathrm{~mL}$ measuring flask reacted with $1.0 \mathrm{~mL}$ DPPH then added absolute ethanol, measured by a spectrophotometer. Antioxidant activity is expressed based on percent inhibition, which is calculated by the formula:

$$
\% \text { inhibition }=\frac{\text { blank absorption }- \text { sample absorption }}{\text { blank absorption }}
$$




\section{Total flavonoids}

Measurement of total flavonoid levels refers to the study of Zou et al. (2004) with modifications. The sample solution of $0.5 \%$ as much as $500 \mu \mathrm{L}$ of each extract in a $10.0 \mathrm{~mL}$ measuring flask was reacted with $0.3 \mathrm{~mL}$ of $5 \% \mathrm{NaNO}_{2}, 4.0 \mathrm{~mL}$ of distilled water, then left for 5 minutes. A solution of $10 \% \mathrm{AlCl}_{3}$ as much as $0.3 \mathrm{~mL}$, was allowed to leave again for 5 minutes. The solution was added $4.0 \mathrm{~mL}$ of $4 \% \mathrm{NaOH}$ and distilled water to the squash boundary mark, then stored in a dark room for 25 minutes. The absorbance was measured at $510 \mathrm{~nm}$ with a spectrophotometer. The standard curve is prepared in the same way using routine $0.1 \%$ as a standard with a concentration range of 100 $300 \mu \mathrm{g} / \mathrm{mL}$. The results are expressed as RE values (routine milligram equivalents in each gram of sample) using the formula:

$$
\operatorname{RE}\left(\frac{\mathrm{mg}}{\mathrm{g}}\right)=\frac{\text { total flawonoid content of the somple }\left(\frac{\mathrm{mg}}{\mathrm{ggem}}\right)}{\text { wright of wrighing of the axtract }\left(\frac{\mathrm{g}}{100 \mathrm{~mL}}\right)}
$$

\section{Total phenolic level}

Measurement of total phenolic levels refers to research by Chang et al. (2001) with modifications. A sample stock of $0.1 \%$ as much as $600 \mu \mathrm{L}$ of each extract was reacted with $500 \mu \mathrm{L}$ Folin-Ciocalteu reagent in a $5.0 \mathrm{~mL}$ flask. The solution is cortexed, left for 5 minutes. The solution was added $750 \mu \mathrm{L}$ of $\mathrm{Na}_{2} \mathrm{CO}_{3} 10 \%$ and distilled water to the boundary mark. The mixture solution was centrifuged 8 minutes, then the supernatant was measured for absorbance at $750 \mathrm{~nm}$ theoretical $\lambda$ with a spectrophotometer. The standard curve is prepared in the same way using $0.1 \%$ gallic acid as a standard with a concentration range of $10-30 \mu \mathrm{g} / \mathrm{mL}$. The results are expressed as GAE values (equivalent milligrams of gallic acid in each gram of sample):

$$
\text { GAE }\left(\frac{m g}{g}\right)=\frac{\text { total phenolic content of the scmple }\left(\frac{\mathrm{mg}}{\mathrm{g}}\right)}{\text { wright of wrighing of the axtract }\left(\frac{\mathrm{g}}{100 \mathrm{~mL}}\right)}
$$

\section{RESULT AND DISCUSSION}

The extraction process of durian fruit peels are done by maceration method. Maceration is a technique that is quite extensive because of its simple and easy technique. Maseration is extraction without heating with soaking simplicia in suitable solvents and assisted by stirring (Departemen Kesehatan, 2000). Maceration techniques can maximize the compounds contained in the sample without using heating so that the compounds are not damaged by heating (Batubara et al., 2009). he results of maceration as much as $500 \mathrm{~g}$ of simplicia powder obtained results and yields as in Table I.

Table I. Randemen of durian fruit peel extract from $500 \mathrm{~g}$ powder weight

\begin{tabular}{cc} 
Samples & Randemen (\%) \\
\hline Durian Medan & 5.15 \\
Durian Monthong & 8.53 \\
\hline
\end{tabular}

The use of ethanol $96 \%$ as a solvent in maceration because ethanol is a recommended solvent and has good properties in attracting most of the active compounds, one of them is flavonoids and polyphenols (Saifudin, 2014). The yield results can be used as information on the possible number of compounds contained in the extract. Table I. shows the largest yield found in the peels of Monthong durian fruit with percent yield of $8.53 \%$ then followed by Medan cultivar of 5.15\%. 


\section{Non-specific parameters}

The drying shrinkage parameter aims to provide information on the value range of compounds lost in the drying process (Departemen Kesehatan, 2000). From the data in Table II. It's known that the shrinkage value of the drying of the two cultivars has a considerable difference in numbers, after the statistical analysis with the independent sample $\mathrm{T}$ test showed that the difference was significant. This informs the difference in cultivars of durian fruit peel samples affecting the value of drying losses. The drying rate of Monthong cultivars has a higher value than Medan cultivars, this means that the number of compounds lost during the heating process is more common in Monthong cultivars. This is possible because the content of volatile compounds in Monthong cultivars is greater. According to Ho and Bhat (2015) differences in plant origin and plant species affect the components of volatile compounds, especially ethyl 2-methylbutanoat and 1-propanethiol.

Table II. Non-specific parameter results of ethanol extract of durian fruit peels

\begin{tabular}{lccc}
\hline \multirow{2}{*}{ Parameter } & \multicolumn{2}{c}{ Results (\%) } & \multirow{2}{*}{ Statistic analysis } \\
\cline { 2 - 3 } & Medan & Monthong & \\
\hline Shrinkage drying & $9.71 \pm 0.96$ & $12.06 \pm 0.34$ & significant difference \\
Water content & $6.12 \pm 0.29$ & $7.16 \pm 0.25$ & Not significantly different \\
$\begin{array}{l}\text { Total ash content } \\
\begin{array}{l}\text { Levels of acid } \\
\text { insoluble ash }\end{array}\end{array}$ & $1.78 \pm 0.21$ & $1.03 \pm 0.07$ & Not significantly different \\
\hline
\end{tabular}

Water content is related to the quality and storage power of an extract. Extracts with high water content will be easily overgrown by fungi (Zainab et al., 2016). Water content of Medan and Monthong cultivar extracts had no significant difference. The durian fruit peel extract of both cultivars includes thick extract. The thick extract category has the range of water content is 5-30\%. In the study obtained water content of $6.12 \%$ for Medan cultivars and $7.16 \%$ for Monthong, these results do not exceed the reference limit, the extracts tested were in accordance with the requirements.

Determination of ash content is closely related to the mineral content contained in an ingredient, the purity and cleanliness of the material (Husna, 2014). Determination of the first ash content is total ash content which indicates the total amount of material after ignoring both physiological ash derived from the plant itself and non-physiological ash which is a residue of foreign material that attaches to the surface of the plant. Both levels of acid insoluble ash are residues obtained from boiling total ash with strong acids. These levels indicate the amount of non-physiological ash such as silica, soil, and sand in plants (World Health Organization, 1998). Table II. shows that the total ash content of the two cultivars has no significant difference, as well as the acid insoluble ash content. The physiological mineral content of durian fruit such as iron, manganese, zinc, copper is below $5 \mathrm{mg} / \mathrm{kg}$ (Gorinstein et al., 2011). The low value of total ash content and acid insoluble ash content indicates mineral content and soil contamination, the sand of the durian fruit peel sample is low.

\section{Specific parameters \\ Organoleptic}

Identification of extract and organoleptic identity is one specific parameter that aims to provide information related to material identity objectively through the initial introduction of materials in a simple way. From the results of observations obtained information extracts of both cultivars have different physical appearance. Table III. Shows parameters of identity and organoleptic of extracts. In terms of the color of the Medan cultivar is brown tends to be black while the Monthong cultivar is 
brown and tend to be reddish. Based on the consistency of the extract, the Medan cultivar is rather hard, while Monthong is soft and sticky. Based on the smell, cultivar monthong has a distinctive smell that is more stinging than Medan cultivar.

Table III. Parameters of identity and organoleptics of extracts

\begin{tabular}{|c|c|c|}
\hline Parameter & Result & \\
\hline $\begin{array}{l}\text { Identity of Extract: } \\
\text { Name of extract } \\
\text { Latin Name } \\
\text { Part of the plant }\end{array}$ & $\begin{array}{l}\text { Durian fruit peel extract } \\
\text { Durio zibethinus Murr } \\
\text { Rind or peel }\end{array}$ & \\
\hline & Medan & Monthong \\
\hline $\begin{array}{l}\text { Organoleptics of Exstract: } \\
\text { Existence } \\
\text { Color }\end{array}$ & $\begin{array}{l}\text { Thick, rather hard } \\
\text { Blackish brown }\end{array}$ & $\begin{array}{l}\text { Thick, soft, sticky } \\
\text { Reddish Brown }\end{array}$ \\
\hline Smell & Typical durian smell (++) & Typical durian smell $(++++)$ \\
\hline
\end{tabular}

\section{Compounds dissolved in certain solvents}

The parameters of the levels of dissolved compounds aim to inform the approximate number of compounds dissolved in certain solvents. Two types of solvents are used, namely water and ethanol. Water solvent to dissolve polar compounds. Ethanol solvent to dissolve semi-polar and non-polar compounds (Saifudin et al., 2011).

Table IV. Parameters of levels of dissolved compounds in specific solvents

\begin{tabular}{lccc}
\hline \multicolumn{1}{c}{ Parameter } & Medan $(\boldsymbol{\%})$ & $\begin{array}{c}\text { Monthong } \\
(\boldsymbol{\%})\end{array}$ & Statistic Analysis \\
\hline $\begin{array}{l}\text { Water soluble } \\
\text { compounds }\end{array}$ & $36.39 \pm 1.42$ & $36.39 \pm 190$ & $\begin{array}{c}\text { Not significantly } \\
\text { different }\end{array}$ \\
$\begin{array}{l}\text { Soluble ethanol } \\
\text { compounds }\end{array}$ & $40.20 \pm 0.18$ & $45.26 \pm ., 02$ & Significantly different \\
\hline
\end{tabular}

Table IV. shows that Medan and Monthong cultivars are more soluble in ethanol solvents than in water solvents. These results indicate that the compounds contained in durian fruit peel extract of both cultivars are semi-polar and non-polar compounds. The standard deviation received in measuring the parameters of dissolved compounds is less than $25 \%$ and the sum between the water soluble compounds and ethanol dissolved compounds is not more than 100\% (Saifudin et al., 2011). In this test the standard deviation is below 6\% (attachment) with the sum of dissolved extracts for Medan cultivars at $76 \%$ and Monthong cultivars at $81 \%$, which means that the measurement results are acceptable. 


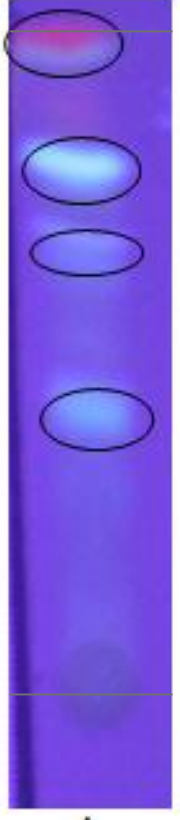

A

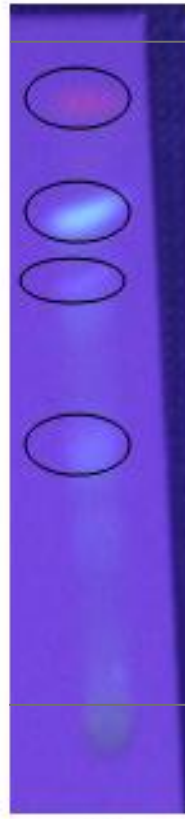

B

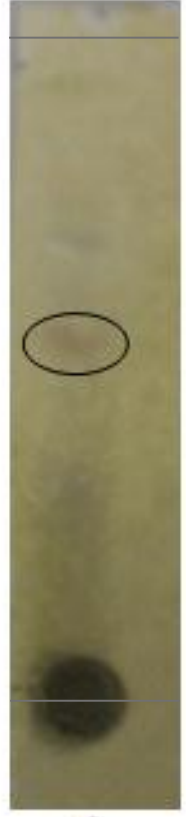

C

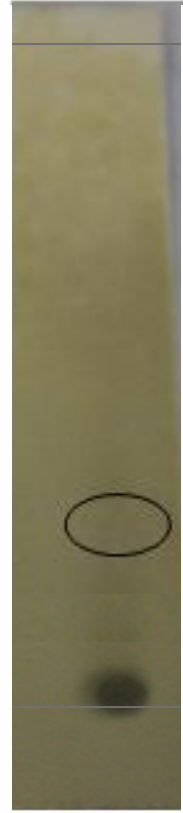

D

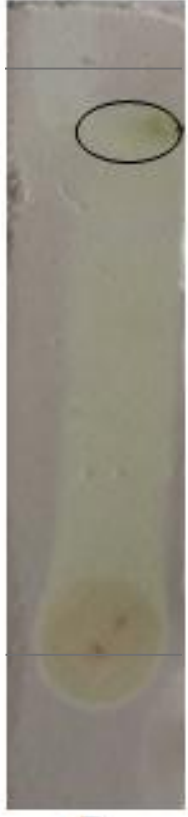

E

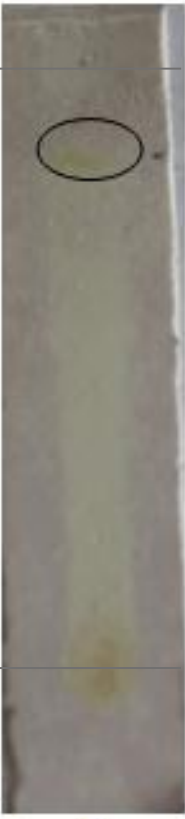

$\mathbf{F}$

Figure 1. Chromatogram of durian fruit peel extract with the stationary phase GF-254 and the mobile phase of chloroform: methanol (8: 2)

(A) Medan cultivar, visualize with sitroborate at UV 366nm

(B) Monthong cultivar, visualize with sitroborate at UV 366nm

(C) Medan cultivar, visualize with $\mathrm{FeCl}_{3}$ in visible light

(D) Monthong cultivar, visualize with $\mathrm{FeCl}_{3}$ in visible light

(E) Medan cultivar, visualize with DPPH in visible light

(F) Monthong cultivators, visualize with DPPH in visible light.

\section{Chromatogram profile}

The TLC system used is a normal phase with a polar stationary phase (silica GF-254) and a nonpolar mobile phase. Identification of compounds were using the same TLC conditions, including plate size $5 \times 1 \mathrm{~cm}$, mobile phase volume of $5 \mathrm{~mL}, 40$ minutes saturation time, number of dots of extract as much as 3 times the spotting, and elution distance of $4 \mathrm{~cm}$. The qualitative test results of chemical extracts of extract by thin layer chromatography (TLC) showed samples of durian peels cultivars Medan and Monthong positively contained flavonoids and phenols and could potentially capture free radicals. This study only identifies flavonoid and phenol compounds because most of the natural ingredients in particular plants contain these compounds.

\section{Antioxidant assay}

Table $\mathrm{V}$. The $\mathrm{IC}_{50}$ values of vitamin $\mathrm{E}$ and durian fruit peels extract

\begin{tabular}{lcc}
\hline \multicolumn{1}{c}{ Compounds } & Mean $\mathbf{I C}_{\mathbf{5 0}} \pm \mathbf{S D}$ & Category* $^{*}$ \\
\hline Vitamin E & $9.85 \pm 0.69$ & Very active \\
Durian Medan & $78.83 \pm 1.67$ & Active \\
Durian Monthong & $72.77 \pm 6.60$ & Active \\
\hline
\end{tabular}

*Category according to Reynertson (2015) 
The radical capture test uses 2,2-diphenyl-1-picrylhydrazyl (DPPH) method through electron capture mechanism and hydrogen donor between DPPH radicals and durian fruit peel extract. DPPH is a stable free radical group with characteristics of electron delocalisation, causing the DPPH molecule not to undergo dimerization. DPPH mixed with antioxidant compounds will change the intensity of color from purple to yellow. This is because the reactive oxygen DPPH molecules receive hydrogen ions from antioxidant compounds (Molyneux, 2004). Table V. displays that $\mathrm{IC}_{50}$ of Medan cultivars were $78.83 \mu \mathrm{g} / \mathrm{mL}$ while Monthong cultivars were $72.77 \mu \mathrm{g} / \mathrm{mL}$. Based on the Reynertson (2015) antioxidant activity category, the $\mathrm{IC}_{50}$ value of vitamin $\mathrm{E}$ was lower than $50 \mu \mathrm{g} / \mathrm{mL}$, indicating that the antioxidant activity was very active, while $\mathrm{IC}_{50}$ durian fruit peel extract of both cultivars was active category because it was in the range of $50-100 \mu \mathrm{g} / \mathrm{mL}$. The test results showed that antioxidant activity $\left(\mathrm{IC}_{50}\right)$ of the durian fruit peels of both cultivars did not differ significantly. Statistical analysis (One Simple T Test) between the results of testing with vitamin E, showed a significant difference, indicating that the antioxidant activity of both cultivars was lower than vitamin E. The antioxidant activity of durian fruit peel extract was produced from flavonoids, phenolics contained in the skin of durian fruit. This result was supported by Batubara's statement (2011), that phenolic compounds in durian fruit showed antioxidant effects on DPPH radicals reinforced by $\mathrm{IC}_{50}$ values of $61.57 \mu \mathrm{g} / \mathrm{mL}$, then in Muhtadi et al. (2014) stated $\mathrm{IC}_{50}$ of antioxidant activity of durian fruit peels as large as $28.83 \pm$ $0.48 \mathrm{mg} / \mathrm{mL}$.

\section{Paramaters of total flavonoids and phenolic levels}

The flavonoid content was measured colorimetrically with $\mathrm{AlCl}_{3}$. Flavonoids are measured as Equivalent Routines from routine standard curve equations. The principle of determining the content of flavonoids based on ortho dihydroxy groups and hydroxy ketone groups on the structure of routine compounds that form complexes with $\mathrm{AlCl}_{3}$ recording (Chang et al., 2001). Routine is a quercetin derivative glycoid glycone. Routine is usually used as standard standard because it has strong antioxidant potential and is able to form color complexes with $\mathrm{AlCl}_{3}$ and complex compounds produced tend to be stable (Casa et al., 2000).

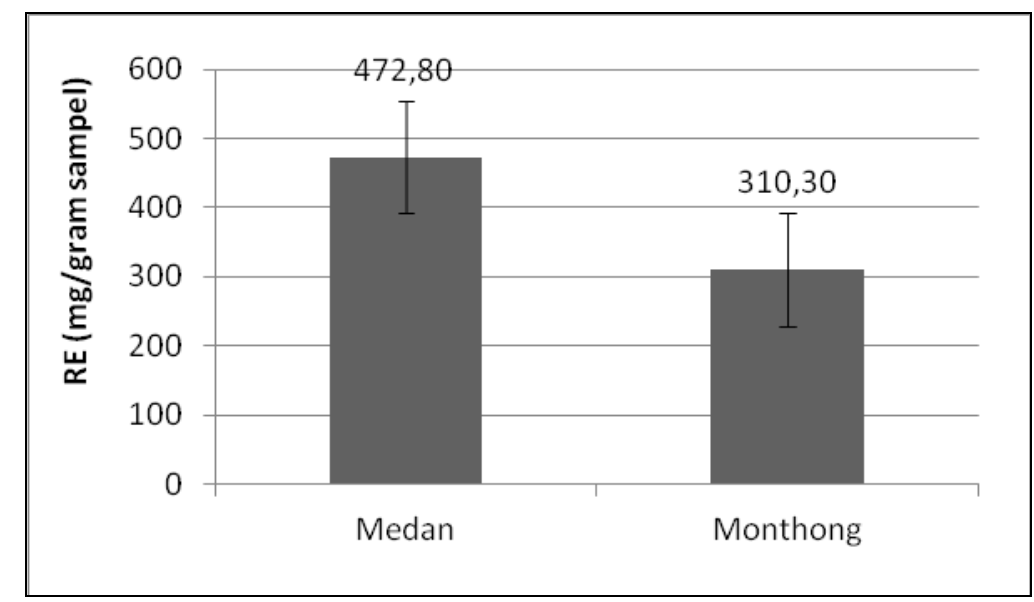

Figure 2. Total flavonoid levels of durian fruit peels extracts of medan and monthong cultivars

Figure 2. shows the result testing for total flavonoid levels of Medan cultivar was 472.80 $\mathrm{mg} /$ gram sample, while Monthong cultivar was $310.30 \mathrm{mg} / \mathrm{gram}$ sample. The levels of both flavonoid cultivars according to statistical analysis were not significantly different. The durian flavonoid content of the tested fruit was higher than the Batubara (2011) reported which obtained flavonoid levels of $64.82 \mathrm{mg} / \mathrm{gram}$ for inner durian fruit peels and $135.76 \mathrm{mg} / \mathrm{gram}$ samples for outer durian fruit peels. High flavonoid content is possible because the durian fruit skin sample used is not separated between 
the inner skin and the outer skin so as to produce more flavonoids. This result is in accordance with the statement of Shui and Leong (2005) and Dembitsky et al (2011) who reported the main flavonoid compounds contained in durian namely routine and quercetin. The study of Toledo et al. (2008) mentions the dominant Monthong cultivar of flavonoid compounds, namely acid caffeat and quercetin.

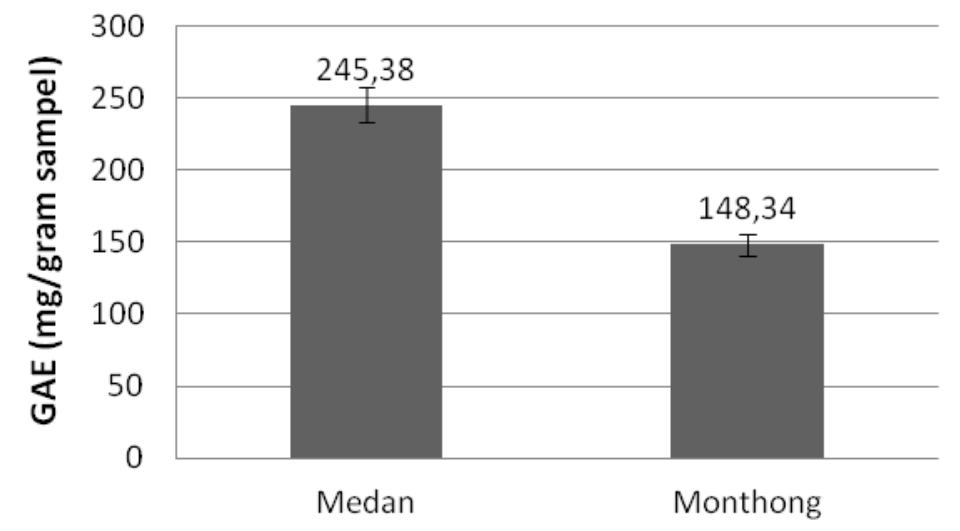

Figure 3. Total phenolic content of Durian fruit peels extracts of Medan and Monthong cultivars

The total phenolic content was measured as Gallic Acid Equivalent (GAE) from the raw curve of gallic acid. The principle of determining phenolic levels is based on the strength of reducing the hydroxy groups present in phenolic compounds. Reaction of Folin Ciocalteu containing phosphotungstate phosphomolibdate will be reduced by phenol compounds to produce blue molybdenum (Huang et al., 2005).

The total phenolics test results for Medan cultivars were $245.38 \mathrm{mg} / \mathrm{gram}$ samples, while Monthong cultivars were $148.34 \mathrm{mg} / \mathrm{gram}$ samples (Figure 3). The total phenolic level of both cultivars according to statistical analysis was not significantly different. The total phenolic content of the durian fruit peel tested was higher than the Batubara study (2011) which obtained a total phenolic level of $71.75 \mathrm{mg} / \mathrm{gram}$ for inner durian fruit peel and $79.49 \mathrm{mg} / \mathrm{gram}$ sample for outer durian fruit peel. High total phenolic content in this research is possible because the durian fruit skin sample used is not separate between the inner and the outer skin. Khoo et al. (2016) study states that phenolic compounds that are dominantly contained in plants include gallic acid, catechin, and cyanidin. It is also indicated that durian fruit contains phenolic compounds as evidenced by the total phenolics test which gives positive results to the gallic acid.

Factors that might influence the amount of flavonoids levels and total phenolics content of both durian fruit cultivars include different levels of sample maturity. Leontowicz et al. (2011) explained that differences in durian maturity level would affect the levels of flavonoids and phenolics produced. The highest content of flavonoids and phenolics is in overcooked fruits, mature and mature and lowest in young fruits. Poovarodom et al. (2010) states that there are several compounds that are only detected in mature or overripe durian fruit, these compounds include caffeat and apigenic acids.

Previous research stated that there was a positive correlation between flavonoid content and phenolic content on antioxidant activity, so that the higher the content of flavonoids and phenolics, the better antioxidant activity (Shui and Leong, 2005; Toledo et al., 2008). This study shows the content of flavonoids and phenolics shows the opposite value of antioxidant activity. Medan cultivars have higher levels of flavonoids and phenolics than Monthong cultivars, but show lower antioxidant activity. This is probably due to differences in chemical structure and differences in the nature of the side group chains in phenolic or flavonoid compounds which can cause different characteristics of the antioxidant activity. Therefore, a sample with a large amount of phenolics and flavonoids does not necessarily give a large response to antioxidant activity (Demiray et al., 2009; Enadis et al., 2003). 
Parameters of ethanol dissolved compounds that show the results of significant differences between Medan and Monthong cultivars indicate that the durian fruit of Monthong cultivar which has a greater dissolved content, besides containing flavonoid compounds as routine and phenolics as gallic acid also contains higher of semi-polar compounds. Research by Poovarodom et al. (2010) reported that other compounds also contributed antioxidant activity to samples of durian fruit skin, one of which was carotenoid compounds such as $\beta$-carotene.

\section{CONCLUSION}

Standardization of durian fruit peels extracts from Medan and Monthong cultivars according to standard procedures from the health department showed no significant differences and all parameters met the criteria requirements. While the antioxidant activity was indicated by $\mathrm{IC}_{50}$ values of each extracts, namely Medan of $78.83 \pm 1.67 \mu \mathrm{g} / \mathrm{mL}$ and Monthong of $72.77 \pm 6.60 \mu \mathrm{g} / \mathrm{mL}$.

\section{ACKNOWLEDGEMENT}

The authors would like to thank the Directorate of Research and Development Kemenristekdikti for funding support through the PUPT Grant scheme. Thank you also to the dean of the Faculty of Pharmacy, Universitas Muhammadiyah Surakarta who has provided facilities for conducting research.

\section{REFERENCES}

Arifin, H., Anggraini, N., Handayani, D., Rasyid, R., 2006, Standarisasi ekstrak etanol daun Eugenia Cumini Merr., J. Sains Tek. Far., 11(2): 88-93.

Batubara., 2011, Antioxidant Activity of Ethanol Extract of Durian (Durio zibethinus Murr) peels and their fraction with DPPH Method. Skripsi. Fakultas Farmasi Universitas Muhammadiyah Surakarta.

Batubara, I., Mitsunaga, T., Ohashi, H., 2009, Screening antiacne potency of Indonesian medicinal plants : antibacterial, lipase inhibition, and antioxidant activities, Journal of Wood Science, 55(3): 230-235.

Casa, C., Villegas, I., Alarco, C., Lastra, D., Motilva, V., Martı, M., 2000,Evidence for protective and antioxidant properties of rutin, a natural flavone, against ethanol induced gastric lesions, Journal of Ethnopharmacology. 71(1-2):45-53.

Chang, S., Wu, J., Wang, S., Kang, P., Yang, N., Shyur, L., 2001, Antioxidant activity of extracts from. Grasas Y Aceites, 49: 3420-3424.

Dembitsky VM, Poovarodom S, Leontowicz H, Leontowicz M, Vearasilp S, Trakhtenberg S, Gorinstein S. 2011, The multiple nutrition properties of some exotic fruits: Biological activity and active metabolites. Food Research International, 44(7): 1671-1701.

Demiray, S., Pintado, M., Castro, P., 2009, Evaluation of phenolic profiles and antioxidant activities of Turkish medicinal plants: Tilia argentea, Crataegi folium leaves and Polygonum bistorta roots. World Academy of Science, Engineering and Technology, 3(6): 307-312.

Departemen Kesehatan., 2000, Parameter Standar Umum Ekstrak Tumbuhan Obat, 77.

European Medicines Agency (EMEA), 2005, Guideline on quality of herbal medicinal products 1/traditional herbal medicinal products, 44 (March), 1-13. Terdapat di:

http://www.ema.europa.eu/docs/en_GB/document_library/Scientific_guideline/2011/09/WC500 113209.pdf.

Enadis, K., Hang, H., Simidou, A., 2003, Structure - Antioxidant Activity Relationship of Ferulic Acid Derivatives : Effect of Carbon Side Chain Characteristic Groups, 1874-1879.

Gorinstein, S., Poovarodom, S., Leontowicz, H., Leontowicz, M., Namiesnik, J., Vearasilp, S.,Tashma, Z., 2011, Antioxidant properties and bioactive constituents of some rare exotic Thai fruits and comparison with conventional fruits In vitro and in vivo studies. Food Research International, 44(7): 2222-2232. 
Ho, L., Bhat, R., 2015, Exploring the potential nutraceutical values of durian (Durio zibethinus L .) An exotic tropical fruit. Food Chemistry, 168: 80-89.

Huang, D., Ou, B., Prior, R., 2005, The chemistry behind antioxidant capacity assays. Agricultural and Food Chemistry, 53: 1841-1856.

Husna, N.E., Asmawati, A., Surwajana, G., 2014, Dendeng Ikan Leubiem (Canthidermis Maculatus) dengan Variasi Metode Pembuatan, Jenis Gula, dan Metode Pengeringan, Jurnal Teknologi dan Industri Pertanian Indonesia, 6(3): 76-81.

Khoo, H. E., Azlan, A., Kong, K. W., Ismail, A., 2016, Phytochemicals and Medicinal Properties of Indigenous Tropical Fruits with Potential for Commercial Development, Evidence-Based Complementary and Alternative Medicine. Volume 2016, Article ID 7591951, 20 pages http://dx.doi.org/10.1155/2016/7591951.

Kunle, Folashade O., Egharevba, Henry, Ahmadu and Ochogu P., 2012, Standardization of herbal medicines, Farmaceutisch Tijdschrift voor Belgie, 4(3): 101-112.

Leontowicz, H., Leontowicz, M., Jesion, I., Bielecki, W., Poovarodom, S., Vearasilp, S., Gorinstein, S., 2011, Positive effects of durian fruit at different stages of ripening on the hearts and livers of rats fed diets high in cholesterol, European Journal of Integrative Medicine, 3(3):e169-e181.

Leontowicz H., Leontowicz M., Haruenkit R., Poovarodom S., Jastrzebski Z., Drzewiecki J., Leticia A., Ayala M., Jesion I., Trakhtenberg S. and Gorinstein S., 2008, Durian (Durio zibethinus Murr.) cultivars as nutritional supplementation to rat's diets, Food Chem Toxicol., 46(2): 581589.

Molyneux, P., 2004, The Use of the Stable Free Radical Diphenylpicryl-hydrazyl (DPPH) for Estimating Antioxidant Activity. Songklanakarin Journal of Science and Technology, 26: 211219.

Muhtadi, Haryoto, Sujono, T. A., Suhendi, A., Yen, K. H., 2014, Antioxidant activity and chemical constituents of some indonesian fruit peels. Medicinal Plants, 6(1): 43-46.

Muhtadi, EM. Sutrisna, Andi Suhendi., 2016, Produksi Obat Herbal Terstandar Antidiabetes dari Pengembangan Kombinasi Ekstrak Channa Striata dan Beberapa Tanaman Obat yang Berkhasiat Sebagai Penurun Kadar Gula Darah, Laporan Penelitian PUPT, Farmasi UMS, Surakarta.

Pandey, A., and Tripathi, S., 2014, Concept of standardization, extraction and pre phytochemical screening strategies for herbal drug, Journal of Pharmacognosy and Phytochemistry, 2(5): 115119.

Poovarodom, S., Haruenkit, R., Vearasilp, S., Namiesnik, J., Cvikrová, M., Martincová, O., Gorinstein, S., 2010, Comparative characterisation of durian, mango and avocado. International Journal of Food Science and Technology, 45(5): 921-929.

Rahayu., 2007, Uji Aktivitas Penangkapan Radikal Fraksi Non Polar Ekstrak Etil Asetat Daun Dewandaru dengan Metode DPPH. Skripsi. Fakultas Farmasi Universitas Muhammadiyah Surakarta.

Reynertson, K. A., 2015, Phytochemical analysis of bioactive constituents from edible myrtaceae fruits. City University New York.

Sachan A.K., Vishnoi G. and Kumar R., 2016, Need of standardization of herbal medicines in modern odern era, International Journal of Phytomedicine, 8(3): 300-307.

Saifudin, A., 2014. Senyawa Alam Metabolit Sekunder. Yogyakarta: Deep publish.

Saifudin, A., Rahayu, V., Teruna, H. Y., 2011, Standardisasi Bahan Obat Alam. Yogyakarta: Graha Ilmu.

Shui, G., Leong, L. P., 2005, Screening and Identification of Antioxidants in Biological Samples Using High-Performance Liquid Chromatography - Mass Spectrometry and Its Application on Salacca edulis Reinw. Journal of Agricultural and Food Chemistry, 53: 880-886.

Toledo, F., Arancibia-avila, P., Park, Y., Jung, S., Kang, S., Heo, B., Zachwieja, Z., 2008, Screening of the antioxidant and nutritional properties, phenolic contents and proteins of five durian cultivars, International Journal of Food Sciences and Nutrition, 59(5): 415-427. 
Voigt, R., 1994, Buku Pelajaran Teknologi Farmasi. Gadjah Mada University Press.

World Health Organization., 1998. Quality control methods for medicinal plant materials World Health Organization Geneva. England: Universal Copyright Convention.

Zainab, Gunanti, F., Witasari, H. A., Edityaningrum, C. A., Murrukmihadi, M., 2016, Penetapan parameter standardisasi non spesifik ekstrak etanol daun belimbing wuluh (Averrhoa bilimbi L.). Dalam Prosiding Rakernas dan Pertemuan Ilmiah Tahunan, Yogyakarta: 210-214.

Zou, Y., Lu, Y., Wei, D., 2004, Antioxidant activity of a flavonoid-rich extract of Hypericum perforatum L. in vitro. Journal of Agricultural and Food Chemistry, 52(16): 5032-5039. 